\title{
Pengembangan Perangkat Pembelajaran Model Discovery learning Berbasis Lingkungan Pada Mata Pelajaran IPA Siswa Sekolah Dasar
}

\author{
Komang Suyani' ${ }^{1}$ I Gede Astawan¹, Ndara Tanggu Renda ${ }^{2}$ iD \\ 123 Jurusan Pendidikan Dasar, Prodi Pendidikan Dasar, Universitas Pendidikan Ganesha, Singaraja, Indonesia \\ *Corresponding author: suyanikomang84@gmail.com
}

\begin{abstract}
Abstrak
Perangkat pembelajaran IPA di sekolah dasar belum menggunakan model pembelajaran dan belum menerapkan lingkungan sebagai sumber belajar siswa. Penelitian ini bertujuan untuk mengetahui validitas perangkat pembelajaran Discovery Learning berbasis lingkungan Pada Mata Pelajaran IPA siswa kelas IV. Jenis penelitian ini adalah development research dengan menggunakan model pengembangan 4D yang terdiri dari define, design, develop, dan disseminate. Populasi dalam penelitian pengembangan ini adalah 133 siswa. Metode pengumpulan data dalam penelitian ini adalah non tes dengan memberikan kuesioner untuk memeroleh penilaian terhadap rencana pelaksanaan pembelajaran yang dinilai oleh pakar. Hasil penelitian ini menunjukkan bahwa validitas rencana pelaksanaan pembelajaran pada kategori sangat baik. Berdasarkan hasil analisis diperoleh simpulan yakni validitas rencana pelaksanaan pembelajaran dinyatakan valid.
\end{abstract}

Kata Kunci: Perangkat Pembelajaran, Discovery Learning, IPA.

\begin{abstract}
Natural Science Learning Tools in elementary schools have not used the learning model and have not applied the environment as a source of student learning. This research study is to study the validity of the environment-based Discovery Learning tool in Natural Science Subjects for Grade IV. The developed learning tool consists of Discovery-based Learning Implementation Plan (RPP) of environment-based learning in natural science subjects for grade IV elementary school students in cluster VII. This type of research is development research using the $4 D$ development model which consists of defining, designing, developing, and disseminating. The population in this development study was 133 students. Data collection methods in this study are non-test by giving a questionnaire to check the learning implementation plan proposed by the expert. The results of this study indicate that: the validity of the learning plan in the category is very good. Based on the analysis results, it can be concluded that the validity of the learning implementation plan is valid.
\end{abstract}

Keywords: Learning Tools, Discovery Learning, Science

\section{Introduction}

Pendidikan merupakan sarana penting untuk meningkatkan kualitas Sumber Daya Manusia (SDM) agar dapat mewujudkan proses pembelajaran yang mengembangkan keaktifkan siswa dan menjamin keberlangsungan pembangunan suatu bangsa (Utami, 2015). Peningkatan kualitas SDM jauh lebih mendesak untuk segera direalisasikan terutama dalam menghadapi era persaingan global. Oleh karena itu, peningkatan SDM sejak dini merupakan hal penting yang harus dipikirkan secara sungguh-sungguh. Salah satu upaya pemerintah untuk meningkatkan SDM adalah melalui perubahan Kurikulum. Kurikulum di Indonesia telah mengalami beberapa perubahan, dan sampai ini berlaku kurikulum 2013. Kurikulum 2013 merupakan penyempurnaan dari Kurikulum Tingkat Satuan Pendidikan (KTSP). Salah satu ciri kurikulum 2013 yang paling mendasar ialah menuntut kemampuan guru dalam berpengetahuan dan mencari pengetahuan sebanyak-banyaknya karena siswa zaman sekarang

$\begin{array}{lll}\text { History: } & & \text { Publisher: Undiksha Press } \\ \text { Received } & : 20 \text { August } 2020 & \text { Licensed: This work is licensed under } \\ \text { Revised } & : 11 \text { September } 2020 & \text { a Creative Commons Attribution 3.0 License } \\ \text { Accepted } & : 8 \text { October } 2020 & \text { Pesember } 2020\end{array}$


telah mudah mencari informasi dengan bebas melalui perkembangan teknologi dan informasi (Tena et al., 2019). Dengan demikian, sangat diperlukan upaya inovasi guru dalam menyiasati pembelajaran di kelas.

Kenyataan dilapangan masih banyak pembelajaran yang berpaku pada buku, hanya memberikan penugasan dalam membelajarkan siswa, dan tidak menekankan pada siswa untuk pemecahan masalah dan mengaplikasikan pengetahuannya. Sehingga pembelajaran terkesan masih didominasi guru dan nilai kompetensi IPA serta keterampilan proses di sekolah dasar masih rendah. Hal ini terungkap dari hasil wawancara, observasi dan studi dokumen yang dilakukan pada tanggal 21-26 oktober serta nilai UTS pada mata pelajaran IPA siswa. Berdasarkan studi pendahuluan yang dilakukan diperoleh bahwa dari seluruh jumlah siswa kelas IV sebanyak 133 siswa, dapat diketahui masih terdapat 96 siswa (72\%) yang belum memenuhi KKM. Hal tersebut merupakan permasalahan yang perlu diatasi. Untuk mengatasi hal tersebut dapat mengembangkan perangkat pembelajaran dengan model pembelajaran yang tepat, di antaranya dapat mengembangkan perangkat pembelajaran dengan model Discovery Learning.

Model pembelajaran Discovery Learning merupakan model pembelajaran kognitif yang menuntut guru lebih kreatif menciptakan situasi yang dapat membuat siswa belajar aktif menemukan pengetahuan sendiri (Nurulhidayah et al., 2020; Putrayasa et al., 2014). Dalam model pembelajaran Discovery Learning, siswa diarahkan untuk menemukan konsep melalui serangkaian data atau informasi yang diperoleh melalui pengamatan atau percobaan yang dilakukan oleh siswa. Discovery Learning merupakan model pembelajaran yang mengarahkan siswa untuk dapat menemukan sesuatu melalui proses pembelajaran yang dilakoninya. Discovery learning bertujuan agar siswa mampu memahami materi sebaik mungkin dan pembelajaran lebih terasa bermakna (Rosarina et al., 2016). Jadi model Discovery Learning merupakan model pemebelajaran yang menuntut guru lebih kreatif dalam menciptakan situasi agar peserta didik belajar aktif dalam menemukan pengetahuannya sendiri sehingga sekiranya dapat meningkatkan kompetensi pengetahuan IPA.

Beberapa penelitian yang mendukung hasil penelitian ini antara lain penelitian yang dilakukan Azura et al., (2019) menyatakan bahwa hasil penelitian menunjukkan bahwa terdapat pengaruh model pembelajaran Discovery learning terhadap hasil belajar siswa pada materi perubahan wujud benda. Sehingga penelitian ini dapat disimpulkan bahwa model pembelajaran Discovery learning layak digunakan untuk proses pembelajaran khususnya pada materi perubahan wujud benda sehingga hasil belajar siswa meningkat. Penelitian yang dilakukan oleh (Jalil et al., 2016) menyatakan bahwa Hasil penelitian menunjukkan bahwa perangkat pembelajaran model DL berbantuan TPI valid, praktis, dan efektif. Perangkat dinyatakan valid dengan kategori baik dan sangat baik. Perangkat dinyatakan praktis dengan mendapat respon positif siswa, dan guru memberikan respon yang baik. Perangkat dinyatakan efektif dengan aktivitas siswa kelas uji coba skala kecil dan luas berada pada kategori baik dan sangat baik. Ada pengaruh aktivitas DL terhadap kemampuan pengetahuan. Ketuntasan klasikal kelas uji coba skala kecil dan luas mencapai KKM $(2,66)$. Peningkatan kemampuan pengetahuan kelas uji coba skala kecil dan luas berada pada kategori sedang. Penelitian yang dilakukan oleh (Hamzah et al., 2020) menyatakan bahwa Hasil pengembangan produk pada uji coba kecil $(81 \%)$ dan uji coba besar $(84 \%)$. Kesimpulan pada pengembangan produk ini adalah valid dan dapat diimplementasikan dalam pembelajaran.

Sesuai dengan permasalahan yang didapatkan bahwa pembelajara masih berpusat pada guru serta kurangnya partisipasi siswa, maka perlu dilakukan penelitian pemgembangan dengan tujuan mengembangkan perangkat pembelajaran model discovery learning berbasis lingkungan pada mata pelajaran ipa siswa kelas IV di SD gugus VII kecamatan sukasada 
tahun pelajaran 2019/2020". Dengan menerapkan model Discovery Learning diharapkan dapat mengatasi masalah yang ada.

\section{Materials and Methods}

Model penelitian ini berfokus pada penelitian pengembangan yang menghasilkan produk pengembangan berupa RPP (Rencana Pelaksanaan Pembelajaran) Discovery Learning Berbasis Lingkungan Pada Mata Pelajaran IPA dengan model pengembangan 4-D terdiri dari empat langkah yakni: define, design, develop, dan disseminate (Purohita, Suardana, Selamet, 2020). Model pengembangan 4D. Azura, Kamariyah, Taufiq (2019) menyatakan bahwa proses pengembangan model pembelajaran Discovery learning dalam penelitian ini mengacu pada model pengembangan yang dikembangkan oleh Thiagarajan, yaitu: 4-D (Four-D) Model. Model pengembangan 4-D terdiri atas 4 tahap utama yaitu: tahap Define, tahap Design, tahap Develop dan tahap Disseminate atau diadaptasikan menjadi model 4-P, yaitu pendefinisian, perancangan, pengembangan, dan penyebaran.

Adapun subjek dan objek penelitian ini, Instrumen Perangkat Pembelajaran Discovery Learning Berbasis Lingkungan sebagai subjek penelitian adalah dua orang dosen dan objek penelitian adalah perangkat pembelajaran model discovery learning berbasis lingkungan diuji validtas oleh dua orang dosen dan dua orang guru kelas IV SD. Variabel bebas adalah variabel yang memengaruhi adanya variabel terikat, variabel bebas dalam penelitian ini adalah Pengembangan Perangkat Pembelajaran Discovery Learning Berbasis Lingkungan. Variabel bebas Pengembangan Perangkat Pembelajaran Discovery Learning Berbasis Lingkungan Model discovery learning berbasis lingkungan adalah suatu pengembangan perangkat pembelajaran dengan model pembelajaran Discovery Learning yang memberikan pengalaman belajar tidak hanya bersifat hafalan namun pengetahuan mereka peroleh sendiri dengan berperan aktif penemuannya sendiri yang di dalamnya diberikan lingkungan sebagai tempat atau wadah untuk mereka melalukan suatu pembelajaran yang bisa menjelaskan konsep-konsep secara alami dan nyata, yang tidak hanya bisa mereka bayangkan seperti belajar dalam ruangan kelas. Oleh sebab itu diperlukan model Discovery Learning pada rencana pelaksanaan pembelajaran (RPP).

Metode pengumpulan data yang dilakukan dalam penelitian ini adalah dengan memberikan kuesioner (angket). "Kuesioner (Angket) merupakan teknik pengumpulan data yang dilakukan dengan cara memberikan seperangkat pertanyaan atau pernyataan tertulis kepada responden untuk dijawab oleh responden tersebut" (Fahmawidiarti et al., 2018; Pujihastuti, 2010). Kuesioner diberikan kepada ahli/pakar yang terdiri dari Dosen di Prodi Pendidikan Guru Sekolah Dasar Universitas Pendidikan Ganesha untuk mengetahui kevalidan sebuah produk perangkat pembelajaran. Sebelum kuesioner diberikan kepada ahli/pakar terlebih dahulu dibuatkan kisi-kisi kuesioner. Tipe pernyataan yang terdapat dalam kuesioner bersifat tertutup, yaitu pernyataan yang diberikan kepada responden dengan mengharapkan jawaban singkat atau mengharapkan responden untuk memilih salah satu alternatif jawaban dari setiap pernyataan yang telah tersedia. Kuesioner ini berbentuk dari skala lima, yang terdiri dari skor (1) sangat kurang baik, (2) kurang, (3) cukup, (4) baik, dan (5) sangat baik.

Metode dan Teknik analisis data yang digunakan dalam pengembangan perangkat pembelajaran Discovery Learning Berbasis Lingkungan yaitu metode analisis deskriptif kualitatif dan metode analisis deskriptif kuantitatif. Metode analisis deskriptif kualitatif dalam penelitian ini untuk menjelaskan mengenai mengolah data berupa masukan, tanggapan, kritik, dan saran dari hasil review para ahli terhadap perangkat pembelajaran yang dihasilkan. Teknik analisis deskriptif kualitatif digunakan untuk menjelaskan dan menganalisis data-data yang dinyatakan dengan kalimat dan kata-kata (Payuyasa, 2017). 
Metode analisis deskriptif kuantitatif digunakan untuk memeroleh rata-rata skor dari masing-masing ahli melalui lembar penilaian. (Purboningsih, 2015) penelitian deskriptif kuantitatif merupakan suatu kegiatan untuk mengumpulkan informasi secara luas mengenai suatu peristiwa atau keadaan suatu variable dengan apa adanya. Skor yang diperoleh kemudiandihitung rata-ratanya untuk mengetahui validitas perangkat pembelajaran yang dikembangkan. Perhitungan rata-rata ideal (Mi) dan standar deviasi ideal (SDi) penelitian ini dilaksanakan dengan maksud mengembangkan perangkat pembelajaran berupa rencana pelaksanaan pembelajaran Discovery Learning Berbasis Lingkungan Pada Mata Pelajaran IPA Siswa Kelas IV SD. Indikator keberhasilan penelitian ini adalah rata-rata skor validitas perangkat pembelajaran berupa rencana pelaksanaan pembelajaran Discovery Learning Berbasis Lingkungan Pada Mata Pelajaran IPA Siswa Kelas IV SD minimal berada pada rentang $3,33<\mathrm{X} \leq 4,00$ dengan kategori baik.

\section{Results and Discussion Hasil}

Pengembangan perangkat pembelajaran berupa rencana pelaksanaan pembelajaran Discovery Learning berbasis lingkungan dalam meningkatkan kompetensi pengetahuan IPA Siswa Kelas IV SD di Gugus VII Kecamatan Sukasada mengikuti langkah-langkah model pengembangan 4D. Langkah-langkah model pengembangan terdiri dari define, design, develop, dan disseminate (Litay et al., 2013) dengan keterbatasan hanya dilakukan penyebaran rencana pelaksanaan pembelajaran pada wali kelas tanpa diadakan uji coba di sekolah. Populasi dalam penelitian ini adalah siswa kelas IV di SD gugus VII kecamatan sukasada tahun pelajaran 2019/2020 dengan jumlah 133 siswa. Adapun hasil dari tahap develop (pemgembangan) perangkat pembelajaran ini setelah melaksanakan perbaikan dan revisi adalah sebagai berikut: (a) Hasil dari isi, desain dan pembuatan produk awal tersebut selanjutnya dinilai (validasi) ke ahli kurikulum dan ahli materi dimana memperoleh hasil uji validitas 25 butir item terhadap perangkat pembelajaran berupa rencana pelaksanaan pembelajaran yang telah dinyatakan valid diperoleh hasil sebesar 1 pada kategori sangat tinggi. (b) Revisi produk, berdasarkan validasi ahli, data yang masuk selanjutnya digunakan sebagai acuan dalam revisi isi perangkat pembelajaran Discovery Learning Berbasis Lingkungan Pada Mata Pelajaran IPA. (c) hasil produk akhir adalah perangkat pembelajaran berupa rencana pelaksanaan pembelajaran Discovery Learning berbasis lingkungan dalam meningkatkan kompetensi pengetahuan IPA siswa kelas IV SD di Gugus VII Kecamatan Sukasada.

Uji reliabilitas dalam penelitian ini menggunakan rumus instrumen menggunakan tingkat percentages of agreements antara kedua ahli yang datanya hanya "ya" atau "tidak" yang terdapat padalampiran uji instrumen "relevan" dan "tidak relevan". Hasil perhitungan reliabilitas instrumen perangkat pembelajaran Discovery Learning Berbasis Lingkungan dapat dikatakan baik jika memiliki koefisien $(\mathrm{R}) \geq 75 \%$, hasil perhitungan reliabilitas memperoleh hasil 100\% dan dapat dinyatakan baik. Adapun masukan, saran, dan komentar yang diberikan oleh dosen sebagai ahli uji yakni: (1) Tambahkan pendekatan saintifik, (2) perbaiki isi kunci jawaban, (3) menambahkan KD dan indikator, 4) materi pembelajaran dilengkapi dengan, dan 5 manambah materi yang dicari di buku siswa dan buku guru, dan kegiatan pembelajaran sesuaikan dengan model pembelajaran.

Analisis deskriptif kuantitatif digunakan untuk memeroleh rata-rata skor dari masingmasing ahli melalui lembar penilaian. Skor yang diperoleh kemudian dihitung rata-ratanya untuk mengetahui validitas perangkat pembelajaran Discovery Learning Berbasis Lingkungan Pada Mata Pelajaran IPA yang dikembangkan. Adapun skor dari validitas perangkat pembelajaran Discovery Learning Berbasis Lingkunga pada Mata Pelajaran IPA dapat diketahui bahwa masing-masing indikator mendapatkan rata-rata skor validasi pada 
rentang $4,01<\mathrm{X} \leq 5,01$ dengan kualifikasi sangat baik. Hal ini menunjukkan perangkat pembelajaran berupa rencana pelaksanaan pembelajaran dapat dinyatakan valid. Rata-rata skor validasi perangkat pembelajaran berupa rencana pelaksanaan pembelajaran Discovery Learning berbasis lingkungan pada mata pelajaran IPA keseluruhan adalah 4,82 . Apabila dikonversikan pada pedoman skala lima, 4,82 termasuk dalam rentang skor $4,01<\mathrm{X} \leq 5,01$ dengan kualifikasi sangat baik. Hal tersebut menunjukkan keseluruhan perangkat pembelajaran berupa rencana pelaksanaan pembelajaran Discovery Learning berbasis lingkungan telah valid dengan kualifikasi sangat baik.

\section{Pembahasan}

Pengembangan perangkat pembelajaran berupa rencana pelaksanaan pembelajaran Discovery Learning Berbasis Lingkungan Pada Mata Pelajaran IPA Siswa Kelas IV di Gugus VII Kecamatan Sukasada berupa Rencana Pelaksanaan Pembelajaran dapat dilaksanakannya kegiatan pembelajaran IPA dengan proses kegiatan ditemukannya konsep atau prinsip yang sebelumnya tidak diketahui ataupun tidak dilaksanakan oleh siswa dalam kegiatan pembelajaran IPA di sekolah dasar. Kegiatan pembelajaran Discovery Learning yang dilakukan siswa dalam pembelajaran IPA dengan berbagai kegiatan seperti menghimpun informasi, membandingkan, mengategorikan, menganalisis, mengintegrasi, mereorganisasikan bahan, serta membuat kesimpulan sebagai produk dari penemuanpenemuannya (Cintia et al., 2018; Dewi et al., 2019). Sehingga dengan adanya penerapan model discovery learning dapat meningkatkan kemampuan penemuan siswa, selain itu model discovery learning menciptakan suasana kondisi belajar di kelas yang awalnya pasif menjadi lebih aktif dan kreatif (Ertikanto et al., 2018; Ratnadewi \& Arini, 2018). Lingkungan sangat berperan dalam pertumbuhan dan perkembangan siswa. Siswa pertama kali belajar dan memahami sesuatu dari lingkungannya. Pemanfaatan lingkungan alam sebagai sumber belajar dapat dilakukan dalam rangka mengembangkan potensi siswa untuk melakukan kegiatan di luar kelas untuk menemukan sebab-sebab sebuah kejadian di sekitarnya, serta mencari hubungan antara fakta-fakta yang ada di lingkungan fisiknya seperti pencemaran sungai dengan pola hidup masyarakat di sekitarnya dan pelaksanaanperaturan atau kepatuhan hokum . Belajar tidak hanya terjadi di ruangan kelas namun, juga di luar ruangan kelas, dalam hal ini lingkungan dijadikan sebagai sumber belajar yang sangat berpengaruh terhadap perkembangan fisik, keterampilan sosial, budaya, perkembangan emosional serta intelektual.

Model discovery learning berbasis lingkungan adalah suatu model pembelajaran yang memberikan pengalaman belajar tidak hanya bersifat hafalan namun pengetahuan mereka peroleh sendiri dengan berperan aktif penemuannya sendiri yang di dalamnya diberikan lingkungan sebagai tempat atau wadah untuk mereka melalukan suatu pembelajaran yang bisa menjelaskan konsep-konsep secara alami dan nyata, yang tidak hanya bisa mereka bayangkan seperti belajar dalam ruangan kelas. (Syaputra, 2016) Sehingga pada akhirnya model Discovery Learning berbasis lingkungan dapat mewujudkan kondisi belajar siswa yang aktif dalam kegiatan belajar, meningkatkan aktivitas guru selama pembelajaran, juga bisa melatih keterampilan guru agar mengubah dari centered learning menjadi student centered, dan pemanfaatan lingkungan sekolah sebagai media pembelajaran dalam proses pembelajaran dapat menimbulkan reaksi siswa terhadap penjelasan guru, memungkinkan siswa untuk menyentuh objek kajian pelajaran, mengkonkretkan konsep yang abstrak, serta dapat mendeskripsikan masalah sehingga dapat di katakan bahwa pembelajaran Discovery Learning terhadap peningkatan hasil belajar siswa lebih baik dari pada model yang diterapkan secara konvensional. Selain itu, dengan model Discovery Learning peserta didik dapat belajar dan membelajarkan temannya, sehingga peserta didik dapat bersosialisasi dengan baik antarteman dan dapat meningkatkan keaktifan sehingga hasil 
belajar peserta didik dapat meningkat dan menjadi lebih baik (Ariani \& Wachidi, 2019; Pratiwi, 2014).

Pengembangan perangkat pembelajaran Discovery Learning berbasis lingkungan dalam meningkatkan kompetensi pengetahuan IPA diperoleh validitas instrumen rencana pelaksanaan pembelajaran sebesar 1 pada kategori sangat tinggi, memperoleh rata-rata skor validasi perangkat pembelajaran berupa rencana pelaksanaan pembelajaran Discovery Learning berbasis lingkungan pada mata pelajaran IPA keseluruhan adalah 4,82 dan sudah dapat dikatakan reliabel dengan nilai (R) koefisien kepraktisan $100 \%$ dikatakan baik. Hasil uji validitas dan reliabilitas ini sesuai dengan penelitian sebelumnya yakni penelitian oleh (Syamsir et al., 2013) diperoleh uji validitas perangkat pembelajaran Discovery Learning dengan rata-rata hasil uji validitas pada predikat baik serta layak digunakan. Penelitian oleh (Azura et al., 2019) hasil penelitian ini menunjukkan bahwa RPP Discovery Learning memperoleh hasil validitas termasuk ke dalam kategori baik. Serta penelitian oleh (Purohita et al., 2020) mengungkapkan bahwa RPP Discovery Learning memperoleh hasil uji validitas pakar pada kategori sangat baik. Keterbatasan perangkat pembelajaran Discovery Learning berbasis lingkungan ini berupa rencana pelaksanaaan pembelajaran dan hanya dilakukan penyebaran rencana pelaksanaan pembelajaran pada wali kelas tanpa diadakan uji coba di sekolah.

\section{Conclusion}

Validitas isi perangkat pembelajaran berupa rencana pelaksanaan pembelajaran Discovery Learning berbasis lingkungan Pada Mata pelajaran IPA siswa kelas IV di Gugus VII Kecamatan Sukasada Tahun Pelajaran 2019/2020 memperoleh rata-rata skor 4.82 pada kategori sangat baik. Dengan adanya penerapan model discovery learning dapat meningkatkan kemampuan penemuan siswa, selain itu model discovery learning menciptakan suasana kondisi belajar di kelas yang awalnya pasif menjadi lebih aktif dan kreatif.

\section{References}

Ariani, P., \& Wachidi, W. (2019). Penerapan Model Pembelajaran Discovery Learning Untuk Meningkatkan Keaktifan Dan Prestasi Belajar Ppkn Siswa Kelas Vii Smp N 8 Rejang Lebong. Jurnal Ilmiah Teknologi Pendidikan, 8(1), 78-87.

Azura, A. R., Kamariyah, N., \& Taufiq, M. (2019). Pengembangan Model Pembelajaran Discovery Learning Terhadap Hasil Belajar Siswa Pada Mata Pelajaran IPA Dengan Materi Perubahan Wujud Benda Kelas V Di Sd Al-Islah Surabaya. Journal of Natural Science Education Research, 1(2), 171-180.

Cintia, N. I., Kristin, F., \& Anugrahaeni, I. (2018). Penerapan Model Pembelajaran Discovery Learning Untuk Meningkatkan Kemampuan Berpikir Kreatif dan Hasil Belajar Siswa. Perspektif Ilmu Pendidikan, 32(1), 69-77. https://doi.org/DOI: https://doi.org/10.21009/PIP.321.8

Dewi, L. V., Ahied, M., Rosidi, I., \& Munawaroh, F. (2019). Pengaruh Aktifitas Belajar Terhadap Hasil Belajar Siswa Menggunakan Model Pembelajaran Discovery Learning Dengan Metode Scaffolding Lus. Jurnal Pendidikan Matematika dan IPA, 10(2), 299213. https://doi.org/10.26418/jpmipa.v10i2.27630

Ertikanto, C., Rosidin, U., Distrik, I. W., Yuberti, Y., \& Rahayu, T. (2018). Comparison of mathematical representation skill and science learning result in classes with problembased and discovery learning model. Jurnal Pendidikan IPA Indonesia, 7(1), 106-113. https://doi.org/10.15294/jpii.v6i2.9512

Fahmawidiarti, M., Kusdiana, A., \& Ganda, N. (2018). Analisis Kesulitan Guru dalam 
Melaksanakan Evaluasi Pembelajaran Bahasa Indonesia di Sekolah Dasar SeKecamatan Cikoneng Ciamis. Pedadidaktika: Jurnal Ilmiah Pendidikan Guru Sekolah Dasar, 5(2), 260-268.

Hamzah, Mu'arifin, Heynoek, F. P., Kurniawan, R., \& Kurniawan, A. W. (2020). Pengembangan Perangkat Pembelajaran Model Discovery Learning Materi Gerak Lokomotor Kelas Rendah Sekolah Dasar. 2(8), 384-394.

Jalil, M., Ngabekti, S., \& Susilowati, S. M. E. (2016). Pengembangan Pembelajaran Model Discovery Learning Berbantuan Tips Powerpoint Interaktif Pada Materi Interaksi Makhluk Hidup Dengan Lingkungan. Refleksi Edukatika, 6(2), 130-137. https://doi.org/10.24176/re.v6i2.604

Litay, T., Mataheru, W., \& Tamalene, H. (2013). Pengembangan Perangkat Pembelajaran Kooperatif Tipe Team Assisted Individualization (TAI) Pada Materi Kesebangunan Segitiga di Kelas IX SMP Kristen YPKPM Ambon. In Journal of Chemical Information and Modeling (Vol. 53, Issue 9).

Nurulhidayah, M. R., Lubis, P. H. M., \& Ali, M. (2020). Pengaruh Model Pembelajaran Discovery Learning Menggunakan Media Simulasi Phet Terhadap Pemahaman Konsep Fisika Siswa. Jurnal Pendidikan Fisika, 8(1), 95. https://doi.org/10.24127/jpf.v8i1.2461

Payuyasa, I. N. (2017). Analisis Wacana Kritis Model Van Dijk Dalam Program Acara Mata Najwa di Metro TV. 5(November), 14-24.

Pratiwi, F. A. (2014). Pengaruh Pengggunaan Model Discovery Learning Dengan Pendekatan Saintifik Terhadap Keterampilan Berpikir Kritis Siswa SMA. Pengaruh Penggunaan Model Discovery Learning Dengan Pendekatan Saintifik Terhadap Keterampilan Berpikir Kritis Siswa Sma, 6, 10.

Pujihastuti, I. (2010). Prinsip penulisian kuesioner penelitian. CEFARS: Jurnal Agribisnis Dan Pengembangan Wilayah, 2(1), 43-56.

Purboningsih, D. (2015). Pengembangan Perangkat Pembelajaran dengan Pendekatan Guided Discovery pada Materi Barisan dan Deret untuk Siswa SMK Kelas X. Seminar Nasional Matematika Dan Pendidikan Matematika UNY 2015, 467-474.

Purohita, I. G. A. A. M., Suardana, I. N., \& Selamet, K. (2020). Pengembangan Perangkat Pembelajaran Discovery Learning Pada Pokok Bahasan Getaran dan Gelombang. 3(April), 12-20.

Putrayasa, I. M., Syahruddin, H., \& Mergunayasa, I. G. (2014). Pengaruh Model Pembelajaran Discovery Learning Dan Minat Belajar Terhadap Hasil Belajar Ipa Siswa. Jurnal Mimbar PGSD Universitas Pendidikan Ganesha, 2(1), 1-11. https://doi.org/http://dx.doi.org/10.23887/jjpgsd.v2i1.3087

Ratnadewi, I. D. A., \& Arini, N. W. (2018). Penerapan Discovery Learning Berbantuan Media Visual Untuk Meningkatkan Hasil Belajar Ips Siswa Kelas V. Jurnal Ilmiah Pendidikan Profesi Guru, 1(1), 20-28. https://doi.org/10.23887/jippg.v1i1.14210

Rosarina, G., Sudin, A., \& Sujana, A. (2016). Penerapan Model Discovery Learning Untuk Meningkatkan Hasil Belajar Siswa Pada Materi Perubahan Wujud Benda. Jurnal Pena Ilmiah, 1(1), 371-380. https://doi.org/10.17509/jpi.v1i1.3043

Syamsir, M., Danial, M., \& Syahrir, M. (2013). Pengembangan Perangkat Pembelajaran IPA SMP Berbasis Discovery Learning Berorientasi Meningkatkan Kemampuan Berpikir Kritis dan Hasil Belajar Peserta Didik. Journal of Chemical Information and Modeling, 
53(9), 1689-1699. https://doi.org/https://doi.org/10.26858/cer.v3i2.13315

Syaputra, S. (2016). Pengaruh Model Pembelajaran Discovery Learning Berbasis Lingkungan Sekolah Terhadap Hasil Belajar Siswa Pada Materi Keanekaragaman Hayati. Jesbio, V(2), 34-39.

Tena, S., Dominikus, W. S., Sukarjita, I. W., \& Sains, F. (2019). Peningkatan Kompetensi Para Guru Sdi Permunas 2 Kupang Melalui Diklat Teknologi Informasi Dan Komunikasi ( Tik ) Serta Pengembangan Media Pembelajaran Matematika dan Sains Berbasis K-13. Jurnal Pengabdian Kepada Masyarakat.

Utami, D. (2015). Pengaruh Metode Brainstorming Terhadap Kemampuan Berpikir Kritis Pada Pembelajaran Ipa. Jurnal Pendidikan Dasar, 6(2), 232. https://doi.org/10.21009/jpd.062.05 